\title{
Liquid and Vapour Phase of Lavandin (Lavandula $\times$ intermedia) Essential Oil: Chemical Composition and Antimicrobial Activity
}

\author{
Stefania Garzoli ${ }^{1, *} \mathbb{( D}$, Giovanni Turchetti ${ }^{2}\left(\mathbb{D}\right.$, Pierluigi Giacomello ${ }^{1}$, Antonio Tiezzi ${ }^{2}$, \\ Valentina Laghezza Masci ${ }^{2}(1)$ and Elisa Ovidi ${ }^{2, *}$ \\ 1 Department of Drug Chemistry and Technology, Sapienza University, 00185 Rome, Italy \\ 2 Department for the Innovation in Biological, Agrofood and Forestal Systems, Tuscia University, \\ 01100 Viterbo, Italy \\ * Correspondence: stefania.garzoli@uniroma1.it (S.G.); eovidi@unitus.it (E.O.); Tel.: +06-499-13611; \\ Fax: +06-499-13602
}

Academic Editors: Francesca Mancianti and Daniela Rigano Received: 19 June 2019; Accepted: 24 July 2019; Published: 25 July 2019

\begin{abstract}
Essential oils from Lavandula genus and the obtained hybrids are widely used for different purposes such as perfume production in the cosmetic field and for its biological properties. This is the first study on the liquid and vapour phase of Lavandula $\times$ intermedia "Grosso" essential oil grown in the Lazio Region, Italy, investigated using headspace coupled to gas chromatography and mass spectrometry (HS-GC/MS). The results showed the most abundant components were linalool and linalyl acetate, followed by 1,8-cineole and terpinen-4-ol, while lavandulyl acetate and borneol were identified as minor compounds, maintaining the same proportion in both the liquid and vapour phase. Furthermore, we tested lavandin liquid and vapour phase essential oil on gram-negative bacteria (Escherichia coli, Acinetobacter bohemicus, and Pseudomonas fluorescens) and gram-positive bacteria (Bacillus cereus and Kocuria marina).
\end{abstract}

Keywords: lavandin essential oil; liquid phase; vapour phase; HS-GC/MS analysis; antibacterial activity

\section{Introduction}

The genus Lavandula belongs to the Lamiaceae family, a medicinal aromatic plant family whose essential oils (EOs) are widely used for applications in food, perfumery, and in the field of cosmetics; it is also important for human health given its potential biological activities [1-6].

Lavandula species are found worldwide and consist of over 39 species, besides various intraspecific taxa and hybrids, which differ in colour and period of flowering, foliage, and resistance to low temperatures [7]. Lavandula angustifolia (also called L. officinalis or L. vera), Lavandula latifolia (spike lavender), and Lavandula $\times$ intermedia Emeric ex Loisel (lavandin or lavandulil), a natural sterile hybrid obtained by crossing L. angustifolia $\times$ L. latifolia are mainly used to produce EOs.

L. $\times$ intermedia is a shrub ranging from 60 to $150 \mathrm{~cm}$, with linear-lanceolate to spathulate leaves, which are often tomentose. Its inflorescence stalk is branched and flowers show a corolla with a bilateral symmetry and are variable in colour from lilac-purple to white, blooming from late June to July.

Lavandin is a much larger plant than the L. angustifolia varieties and is much appreciated for its EO yield. This product is widely used all over the world by the fragrance industry and is a common ingredient in soaps, laundry detergents, skin care, perfumes, and cleaning products.

L. $\times$ intermedia is present in Spain, France, and Italy with different cultivars among which is L. X intermedia var. "Grosso"; it is characterised by dark violet-blue flowers and is the most widely used for EO production [7]. 
EOs, particularly abundant in aromatic plants, play a fundamental role in plant protection against pathogens such as bacteria, fungi, and insects. Furthermore, they attract some insects to allow the fertilization process by pollen and seed dispersion $[8,9]$. They are a hydrophobic complex mixture of volatile compounds and are mainly composed of terpenes biogenerated by the mevalonate pathway. These volatile molecules include monoterpenes (hydrocarbon and oxygenated monoterpens), and sesquiterpenes (hydrocarbon and oxygenated sesquiterpens) [10]. They also contain phenolic compounds derived from the shikimate pathway. Thanks to their chemical composition, EOs possess antioxidant, anti-inflammatory, antimicrobial, antifungal, and anticancer properties [11-13].

Different biological activities were found in common lavender and lavandin EOs such as anxiolytic, antioxidant, anti-inflammatory, antidepressant, analgesic, smooth-muscle relaxant, anti-parasitic, anticancer, and apoptosis induction activity, as well as having beneficial immunomodulatory effects on wound healing [14-21]. Moreover, it was reported that the EOs obtained from Lavandula are active on many types of bacteria such as foodborne pathogens, human pathogenic bacteria, and environmental bacteria [22-27]. Furthermore, Lavandula $\times$ intermedia and Lavandula Angustifolia essential oils, rich in specific constituents such as linalool, camphor, and 1,8-cineole, possess antibacterial activities against Listeria monocytogenes, especially against isolates from a clinical environment [28].

In the present study, we have analysed the chemical composition of the liquid and vapour phase of L. $\times$ intermedia cv. "Grosso" essential oil (LEO) grown in the Lazio Region, Italy, investigated by headspace coupled to gas chromatography and mass spectrometry (HS-GC/MS). We further studied LEO's antimicrobial properties against gram-negative bacteria $\left(\mathrm{G}^{-}\right)$(Escherichia coli, Acinetobacter bohemicus, and Pseudomonas fluorescens) and gram-positive bacteria $\left(\mathrm{G}^{+}\right)$(Bacillus cereus and Kocuria marina).

\section{Results}

\subsection{LEO Chemical Composition}

GC-MS analysis of the liquid phase showed the presence of 26 compounds (Table 1), of which $89.2 \%$ were monoterpenoids and $3.1 \%$ were sesquiterpenoids The most abundant components were linalool $(41.6 \%)$ and linalyl acetate $(23.0 \%)$, followed by 1,8 -cineole $(5.2 \%)$ and terpinen-4-ol $(4.8 \%)$. Lavandulyl acetate (3.2\%) and borneol (2.8\%) were identified as minor compounds. Headspace GC-MS analysis revealed different results. The percentages of the most volatile compounds increased while that of the highest boiling compounds decreased as shown in Table 1. All the lower boiling compounds showed a greater abundance. More specifically, $\alpha$-pinene increased to $8.7 \%$ and 1,8 -cineole reached $19.8 \%$. In contrast, compounds eluted subsequently from the chromatographic column recorded a decrease in their abundance compared to the analysis of the liquid phase. For example, linalool decreased to $35.8 \%$, linalyl acetate to $7.5 \%$, and terpinen-4-ol to $2.9 \%$.

Table 1. Chemical composition (\%) of Lavandula $\times$ intermedia cv. "Grosso" essential oil (LEO).

\begin{tabular}{|c|c|c|c|c|c|c|}
\hline No. & Component $^{1}$ & LRI $^{\text {lit } 2}$ & LRI $^{3}$ & LRI $^{4}$ & $\begin{array}{l}\text { GC Peak } \\
\text { Area (\%) }\end{array}$ & $\begin{array}{c}\text { HS-GC Peak } \\
\text { Area (\%) }\end{array}$ \\
\hline 1 & $\alpha$-pinene & 1021 & 1019 & 935 & 1.1 & 8.7 \\
\hline 2 & camphene & 1065 & 1055 & 946 & 0.5 & 3.7 \\
\hline 3 & $\beta$-pinene & 1105 & 1100 & 981 & 0.4 & 2.8 \\
\hline 4 & myrcene & 1156 & 1152 & 984 & 1.5 & 4.9 \\
\hline 5 & $\alpha$-phellandrene & 1160 & 1161 & 999 & 0.1 & 0.7 \\
\hline 6 & limonene & 1198 & 1195 & 1025 & 1.0 & 3.5 \\
\hline 7 & 1,8-cineole & 1209 & 1210 & 1028 & 5.2 & 19.8 \\
\hline 8 & (Z)- $\beta$-ocimene & 1237 & 1231 & 1038 & 0.9 & - \\
\hline 9 & $\gamma$-terpinene & 1241 & 1235 & 1046 & 0.2 & - \\
\hline 10 & trans- $\beta$-ocimene & 1276 & 1275 & 1055 & 0.7 & - \\
\hline 11 & terpinolene & 1282 & 1283 & 1072 & 0.4 & - \\
\hline 12 & o-cymene & 1287 & 1290 & 1025 & 0.2 & 1.7 \\
\hline
\end{tabular}


Table 1. Cont.

\begin{tabular}{ccccccc}
\hline No. & Component ${ }^{\mathbf{1}}$ & LRI $^{\text {lit 2 }}$ & LRI $^{3}$ & LRI $^{\mathbf{4}}$ & $\begin{array}{c}\text { GC Peak } \\
\text { Area (\%) }\end{array}$ & $\begin{array}{c}\text { HS-GC Peak } \\
\text { Area (\%) }\end{array}$ \\
\hline 13 & hexyl isobutyrate & 1335 & 1333 & 1145 & 0.3 & - \\
14 & 1-octen-3-yl-acetate & 1401.9 & 1400 & 1122 & 0.5 & 0.7 \\
15 & hexyl butanoate & 1410 & 1414 & 1177 & 0.5 & - \\
16 & 1-octen-3-ol & 1458 & 1461 & 970 & 0.3 & 0.4 \\
17 & camphor & 1507 & 1500 & 1133 & 6.0 & 4.4 \\
18 & linalool & 1537 & 1539 & 1092 & 41.6 & 35.8 \\
19 & linalyl acetate & 1553 & 1549 & 1245 & 23.0 & 7.5 \\
20 & lavandulyl acetate & 1584 & 1580 & 1265 & 3.2 & 0.8 \\
21 & terpinen-4-ol & 1603 & 1600 & 1174 & 4.8 & 2.9 \\
22 & $(E)-\beta$-caryophyllene & 1613 & 1615 & 1428 & 1.3 & - \\
23 & (Z)- $\beta$-farnesene & 1630 & 1635 & 1445 & 1.3 & - \\
24 & $\alpha$-terpineol & 1675 & 1680 & 1185 & 1.6 & 0.4 \\
25 & $\gamma$-muurolene & 1685 & 1687 & 1508 & 0.5 & - \\
26 & borneol & 1717 & 1721 & 1158 & 2.8 & 1.2 \\
Total (\%) & & & & & 99.9 & 99.9 \\
Monoterpenoids & & & & 89.2 & 94.4 \\
Sesquiterpenoids & & & & 3.1 & - \\
Others & & & & & 7.6 & 5.5 \\
\hline
\end{tabular}

${ }^{1}$ Elution order on polar column; ${ }^{2}$ Linear retention indices from literature; ${ }^{3}$ Linear retention indices measured on polar column; ${ }^{4}$ Linear retention indices measured on apolar column. HS-GC: Headspace coupled to gas chromatography.

Table 2 shows the qualitative aspects of LEO. The amounts of the components found were in line with the levels accepted by the European Pharmacopeia (EPh). Only linalyl acetate was slightly below the limits set by the EPh.

Table 2. Percentage of the main compounds in the LEO sample in comparison with the accepted percentages by European Pharmacopoeia (EPh).

\begin{tabular}{ccc}
\hline Component & EPh & Lavandin \\
\hline linalool & $25-45$ & 41.6 \\
linalyl acetate & $25-46$ & 23.0 \\
1,8-cineole & max. 2.5 & 5.2 \\
camphor & $12-18$ & 6.0 \\
\hline
\end{tabular}

\subsection{LEO Antibacterial Activity-Agar Diffusion Method}

The antibacterial activity of LEO was assessed according to the inhibition zone diameter (halo) and the results obtained are summarised in Table 3 . In the $\mathrm{G}^{-}$group, an inhibition halo of $8.5 \pm 0.7 \mathrm{~mm}$ was measured for $P$. fluorescens, while relative antibiotic control using gentamicin (gen) was $25.5 \pm 0.7 \mathrm{~mm}$; E. coli showed an inhibition halo of $13 \pm 1.41 \mathrm{~mm}$ (gen $=16.5 \pm 2.12 \mathrm{~mm}$ ) whereas A. bohemicus exhibited a halo of $47 \pm 4.24 \mathrm{~mm}$ (gen $=34.5 \pm 0.7 \mathrm{~mm}$ ). In the $\mathrm{G}^{+}$group tested, the K. marina inhibition halo was $14.5 \pm 2.12 \mathrm{~mm}(\mathrm{gen}=27 \pm 2.83 \mathrm{~mm})$ and that for B. cereus was $21.5 \pm 0.7 \mathrm{~mm}(\mathrm{gen}=28.5 \pm 0.7 \mathrm{~mm})$.

\subsection{Minimum Inhibitory Concentration (MIC)}

The MIC represents the lowest concentration of antimicrobial agent that completely inhibits growth. Values are reported in percentage of LEO (Table 4) revealing that the most resistant strain was P. fluorescens $\left(\mathrm{MIC}_{\mathrm{LEO}}=3.75 \%, \mathrm{MIC}_{\mathrm{GEN}}=1.56 \mu \mathrm{g} / \mathrm{mL}\right)$, followed by E. coli $\left(\mathrm{MIC}_{\mathrm{LEO}}=1.87 \%, \mathrm{MIC}_{\mathrm{GEN}}\right.$ $=3.12 \mu \mathrm{g} / \mathrm{mL})$ and K. marina $\left(\mathrm{MIC}_{\mathrm{LEO}}=1.87 \%, \mathrm{MIC}_{\mathrm{GEN}}=0.39 \mu \mathrm{g} / \mathrm{mL}\right)$, B. cereus $\left(\mathrm{MIC}_{\mathrm{LEO}}=0.94 \%\right.$, $\left.\mathrm{MIC}_{\mathrm{GEN}}=1.56 \mu \mathrm{g} / \mathrm{mL}\right)$, and $A$. bohemicus $\left(\mathrm{MIC}_{\mathrm{LEO}}=0.47 \%, \mathrm{MIC}_{\mathrm{GEN}}=0.08 \mu \mathrm{g} / \mathrm{mL}\right)$. No bacterial growth occurred in the sterility control, while regular growth was recorded in the negative control. In all strains tested, DMSO antibacterial activity was not present for the $\mathrm{MIC}_{\mathrm{LEO}}$ concentrations used. 
Table 3. Growth inhibition halo $(\mathrm{mm})$ for LEO and the positive control (gentamicin) against the five tested $\mathrm{Gram}^{+}$and $\mathrm{Gram}^{-}$bacterial strains ( $p$ values $\left.\leq 0.05\right)$.

\begin{tabular}{cccc}
\hline & Agar Diffusion Test & LEO $(\mathbf{1 0} \boldsymbol{\mu L})$ & Gen $(\mathbf{2 0} \boldsymbol{\mu g})$ \\
\hline Strain & halo \pm SD $(\mathrm{mm})$ & halo \pm SD $(\mathrm{mm})$ \\
\hline \multirow{3}{*}{$\mathrm{Gram}^{-}$} & Escherichia coli & $13.0 \pm 1.41$ & $16.5 \pm 2.12$ \\
& Acinetobacter bohemicus & $47.0 \pm 4.24$ & $34.5 \pm 0.70$ \\
& Pseudomonas fluorescens & $8.5 \pm 0.70$ & $25.5 \pm 0.70$ \\
\hline \multirow{2}{*}{$\mathrm{Gram}^{+}$} & Bacillus cereus & $21.5 \pm 0.70$ & $28.5 \pm 0.70$ \\
& Kocuria marina & $14.5 \pm 2.12$ & $27.0 \pm 2.83$ \\
\hline
\end{tabular}

Table 4. Minimum inhibitory concentration (MIC) and Minimum bactericidal concentration (MBC) means for LEO expressed in percentage values (\%) and the positive control (gentamicin) expressed in $\mu \mathrm{g} / \mathrm{mL}$ against the five tested bacterial strains.

\begin{tabular}{|c|c|c|c|c|c|}
\hline & \multirow{2}{*}{$\begin{array}{c}\text { Microdilution Test } \\
\text { Strain }\end{array}$} & \multicolumn{2}{|c|}{ LEO } & \multicolumn{2}{|c|}{ Gen } \\
\hline & & $\begin{array}{c}\text { MIC } \\
(\% \text { Mean })\end{array}$ & $\begin{array}{c}\text { MBC } \\
(\% \text { Mean })\end{array}$ & $\begin{array}{c}\text { MIC } \\
\left(\mu \mathrm{g} / \mathrm{mL}_{\text {Mean }}\right)\end{array}$ & $\begin{array}{c}\text { MBC } \\
\left(\mu \mathrm{g} / \mathrm{mL}_{\text {Mean }}\right)\end{array}$ \\
\hline \multirow{3}{*}{$\mathrm{Gram}^{-}$} & E. coli & 1.87 & 1.87 & 3.12 & 6.25 \\
\hline & A. bohemicus & 0.47 & 0.47 & 0.08 & 0.31 \\
\hline & P. fluorescens & 3.75 & 7.51 & 1.56 & 6.25 \\
\hline \multirow{2}{*}{$\mathrm{Gram}^{+}$} & B. cereus & 0.94 & Bacteriostatic & 1.56 & 3.12 \\
\hline & K. marina & 1.87 & Bacteriostatic & 0.39 & 1.56 \\
\hline
\end{tabular}

\subsection{Minimum Bactericidal Concentration (MBC)}

$\mathrm{MBC}$ is expressed as the lowest concentration of essential oil where no visible growth on agar occurred. LEO tested on the $\mathrm{G}^{+}$group displayed a bacteriostatic effect, while on the $\mathrm{G}^{-}$group it recorded results that were consistent with the MIC data recorded before: $P$. fluorescens showed an MBC of $7.50 \%$, E. coli was $1.87 \%$, and A. bohemicus was $0.47 \%$; higher values of both MIC and MBC were obtained by using gen as a positive control (Table 4).

\subsection{Vapour Phase Test (VPT)}

The VPT used to evaluate the antimicrobial activity of the LEO vapour phase is shown in Table 5. After $24 \mathrm{~h}$ of incubation time, differing results emerged: For P. fluorescens, the MIC was higher than $40 \mu \mathrm{L}$ whereas K. marina, E. coli, and B. cereus recorded an MIC of $20 \mu \mathrm{L}$. A. bohemicus recorded the lowest level, with an MIC of $2 \mu \mathrm{L}$. After seven days the plates were checked to evaluate the bactericidal and bacteriostatic activity. No differences were found in B. cereus and P. fluorescens compared with the previous check, recording an MBC of $20 \mu \mathrm{L}$ and more than $40 \mu \mathrm{L}$, respectively; moreover in E. coli and K. marina, colonies were found in the 2 and $20 \mu \mathrm{L}$ treatments while MBC was $40 \mu \mathrm{L}$. In A. bohemicus, the $\mathrm{MBC}$ was $20 \mu \mathrm{L}$. 
Table 5. LEO vapour phase test showing minimum inhibitory concentration (MIC) and minimum bactericidal concentration means (MBC) expressed in $\mu \mathrm{L}$ against the five bacteria tested.

\begin{tabular}{cccc}
\hline & \multicolumn{3}{c}{ LEO VPT (Vapour Phase Test) } \\
\cline { 2 - 4 } & Strain & MIC $\left(\mu \mathrm{L}_{\text {Mean }}\right)$ & $*$ MBC $\left(\mu \mathrm{L}_{\text {Mean }}\right)$ \\
\hline \multirow{2}{*}{ Gram $^{-}$} & E. coli & 20 & 40 \\
& A. bohemicus & $<2$ & 20 \\
& P. fluorescens & $>40$ & $>40$ \\
\hline \multirow{2}{*}{$\mathrm{Gram}^{+}$} & B. cereus & 20 & 20 \\
& K. marina & 20 & 40 \\
\hline
\end{tabular}

\section{Discussion}

LEO liquid and vapour phases were investigated by HS-GC/MS analysis and the presence of monoterpenoids and sesquiterpenoids were highlighted. The most abundant components were linalool and linalyl acetate followed by eucalyptol and terpinen-4-ol, while lavandulyl acetate and borneol were identified as minor compounds. These molecules are mainly responsible for lavandin's characteristic flavour and for their biological and therapeutic properties [29]. Depending on the different types of lavandin, variations in the chemical composition were found. Ghelardini et al. (1999) [30] described the chemical composition of L. angustifolia essential oil of Italian origin, characterised by linalool $(31.5 \%)$, linalyl acetate $(43.0 \%)$, and $\beta$-caryophyllene $(5.0 \%)$ as the main compounds. Caputo et al. (2016) [31] analysed L. angustifolia essential oil obtained from the hydrodistillation of the plant grown in Salerno (Campania, Italy) and showed a composition rich in linalool (33.1\%) and linalyl acetate $(10.4 \%)$ and with low percentages of minor compounds. Iranian lavandin was characterised by 1,8-cineole $(47.9 \%)$ as its main component followed by borneol $(26.4 \%)$ and camphor $(14.4 \%)$ [32] (Bajalan et al. 2017), while Romanian lavandin essential oil was richer in camphor and 1,8-cineole [33]. The essential lavender oil grown in India consisted of linalool (28.06\%) and linalyl acetate (47.5\%) [34]. The major compounds of a Lavandula hybrid grown in Northern Italy were linalyl acetate and borneol, which together accounted for $70 \%$ [35]. In our study, the sum of these two compounds did not exceed $25.8 \%$ and LEO revealed a high content of linalool (41.6\%), while linalyl acetate reached $23.0 \%$; 1,8 -cineole $(5.2 \%)$ and camphor $(6.0 \%)$ were present as secondary compounds. A previous study carried out on the same type of lavandin grown in Tuscany, Italy, [36] reported that linalyl acetate amounted to $14.7 \%, 1,8$-cineole $7.8 \%$, and camphor $7.7 \%$. All these variations in the percentages of the compounds detected could be either due to the cultivation area's altitude or its microclimate. As for the quality of the LEO obtained, the component amounts found were in line with the levels accepted by the European Pharmacopeia (EPh) (Table 2). Only linalyl acetate was slightly below the limits set by EPh.

The results obtained from the different tests on bacteria showed that $A$. bohemicus was the more sensitive strain to LEO with an inhibition halo of $47 \mathrm{~mm}$ and an MIC of $0.47 \%$ in the broth microdilution test, followed by B. cereus with a halo of $21.5 \mathrm{~mm}$ and an MIC of $0.94 \%$. E. coli and K. marina showed similar values, both as regards the disk diffusion test (13.0 and $14.5 \mathrm{~mm}$, respectively) and the microdilution test (both 1.87\%). P. fluorescens proved to be the most resistant of all bacteria tested with an inhibition halo of $8.5 \mathrm{~mm}$ and an MIC of $3.75 \%$. As seen in Table 4, the MBC values showed bactericidal activity of LEO at the MIC concentration for A. bohemicus and E. coli, while for P. fluorescens the MIC increased to $7.5 \%$. This bactericidal effect occurred only for the $\mathrm{G}^{-}$bacteria, while for the $\mathrm{G}^{+}$ bacteria bacteriostatic effects were observed, contributing to the formation of colonies after inhibition agent removal (results of the agar diffusion test are shown in Figure 1). Furthermore, in the VPT, A. bohemicus proved the most sensitive to LEO treatments with an MIC lower than the minimum concentration used for the test; B. cereus, E. coli, and K. marina recorded an identical MIC, varying 
slightly from the data previously obtained in the liquid phase. P. fluorescens achieved an MIC higher than the maximum concentration tested, $40 \mu \mathrm{L}$.

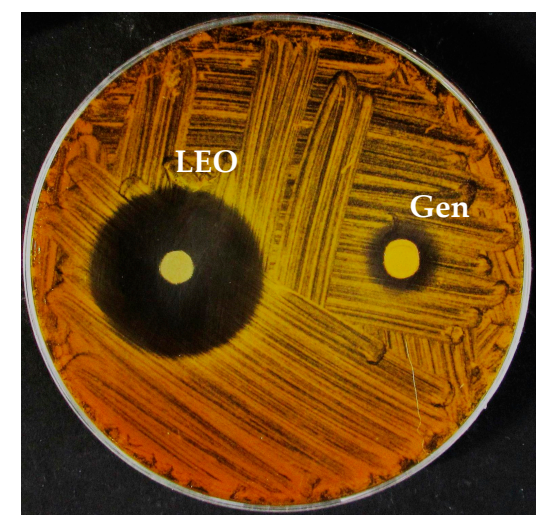

Figure 1. Representative image showing antibacterial activity against a bacterial strain.

\section{Materials and Methods}

\subsection{Plant Materials}

The LEO (IT BIO 007 D86K, lot number MGL01/18) was directly provided by the agricultural enterprise, Azienda Agricola Podere dell'Arco (Viterbo, Lazio), as a steam-distilled sample obtained from a cultivar of lavandin (L. $\times$ intermedia "Grosso").

\subsection{Gas Chromatography-Mass Spectrometry (GC-MS) Analysis}

The essential oil was analysed by gas chromatograph directly coupled to a mass spectrometer (MS) Perkin Elmer Inc., Clarus 500 model (Waltham, MA, USA). The GC was equipped with two columns, one of which was a Restek Stabilwax (fused-silica) polar capillary column, and the other was a Varian (VF-1ms) apolar column. Helium was used as carrier gas at a flow rate of $1 \mathrm{~mL} / \mathrm{min}$ [37]. The Restek column was operated using an injector temperature of $280^{\circ} \mathrm{C}$ and the following oven temperature program: Isothermal at $60^{\circ} \mathrm{C}$ for $5 \mathrm{~min}$, then ramped to $220^{\circ} \mathrm{C}$ at a rate of $5^{\circ} \mathrm{C} \mathrm{min}^{-1}$, and finally isothermal at $220^{\circ} \mathrm{C}$ for $20 \mathrm{~min}$. The other apolar column was operated using an injector temperature of $280^{\circ} \mathrm{C}$ and the following oven temperature program: Isothermal at $60^{\circ} \mathrm{C}$ for $5 \mathrm{~min}$, then ramped to $220^{\circ} \mathrm{C}$ at a rate of $5{ }^{\circ} \mathrm{C} \mathrm{min}-1$, a second ramp to $260{ }^{\circ} \mathrm{C}$ at a rate of $5{ }^{\circ} \mathrm{C} \mathrm{min} \mathrm{m}^{-1}$ and finally isothermal at $260^{\circ} \mathrm{C}$ for $10 \mathrm{~min}$. One microlitre of lavandin $\mathrm{EO}$ was diluted in $1 \mathrm{~mL}$ of methanol and the injection volume was $1 \mu \mathrm{L}$. The injector split ratio was 1:20. Mass spectra were recorded at $70 \mathrm{eV}$ (EI: electronic impact) and were scanned in the range 40-400 m/z. The GC-TIC (total ion current) mass spectra were obtained by data analysis software (TurboMass ${ }^{\mathrm{TM}}$ GC/ MS PerkinElmer). The LEO constituents were identified by comparison of their linear retention indices (LRIs), (relative to C8-C30 aliphatic hydrocarbons, Ultrasci injected into both polar and apolar columns under the same operating conditions described above) with available retention data in the literature. Further identification of all components was made by matching their mass spectra with those stored in the Wiley and NIST02 mass spectra libraries database. GC-FID (flame-ionization detector) analysis was performed under the same experimental conditions using the polar column as described for the GC-MS measurements. The FID temperature was $280^{\circ} \mathrm{C}$. Relative amounts of the essential oil components were obtained by peak area normalisation without the use of an internal standard or correction factors and expressed in percentages. All analyses were repeated twice.

\subsection{Headspace GC-MS Analysis}

The volatile constituents were analysed by a PerkinElmer Inc., Headspace Turbomatrix 40 autosampler coupled to GC and GC-MS (Waltham, MA, USA). [38,39]. The procedures were 
optimised. The gas phase of the sealed vials was equilibrated for $20 \mathrm{~min}$ at $60^{\circ} \mathrm{C}$ and was followed immediately by compound desorption into the GC injector in splitless mode. Quantification of compounds was performed by GC-FID under the same conditions described above.

\subsection{Microorganisms Tested and Growth Conditions}

Bacterial strains were obtained from the culture collections of Plant Cytology and Biotechnology Laboratory of Tuscia University and the Institute of Pharmacy and Molecular Biotechnology at Heidelberg University. Five microbial cultures belonging to gram-positive $\left(\mathrm{G}^{+}\right)$and gram-negative $\left(\mathrm{G}^{-}\right)$bacteria were tested: E. coli American Type Culture Collection-ATCC $25,922\left(\mathrm{G}^{-}\right)$, B. cereus ATCC $10,876\left(\mathrm{G}^{+}\right)$, A. bohemicus DSM 102,855 $\left(\mathrm{G}^{-}\right)$, K. marina DSM $16,420\left(\mathrm{G}^{+}\right)$, and P. fluorescens ATCC $13,525\left(\mathrm{G}^{-}\right)$.

All tested bacterial strains were maintained on Lysogeny Broth agar (LB agar preparation: $10 \mathrm{~g}$ tryptone, $5 \mathrm{~g}$ yeast extract, $10 \mathrm{~g} \mathrm{NaCl}$, and $15 \mathrm{~g}$ agar per litre, autoclaved at $121{ }^{\circ} \mathrm{C}$ for $20 \mathrm{~min}$ ) at different temperatures: $26^{\circ} \mathrm{C}$ for B. cereus, P. fluorescens, and A. bohemicus, and $37^{\circ} \mathrm{C}$ for K. marina and $E$. coli. All inocula were prepared with fresh cultures plated the day before the test.

\subsection{Agar Diffusion Method}

Fresh bacterial strains were suspended in Lysogeny Broth (LB preparation: $10 \mathrm{~g}$ tryptone, $5 \mathrm{~g}$ yeast extract, $10 \mathrm{~g} \mathrm{NaCl}$ per litre, autoclaved at $121^{\circ} \mathrm{C}$ for $20 \mathrm{~min}$ ) to obtain a turbidity of $0.5 \mathrm{McFarland}$ (approximately $10^{8}$ Colony Forming Unit $/ \mathrm{mL}-\mathrm{CFU} / \mathrm{mL}$ ) and then seeded on LB agar. Sterile disks ( $6 \mathrm{~mm}$ diameter) were placed on the agar and impregnated with $10 \mu \mathrm{L}$ of pure LEO. As a positive control, $2 \mu \mathrm{L}$ of gentamicin from a stock solution $(10 \mathrm{mg} / \mathrm{mL})$ was used.

The inhibitory activity was recorded as $\mathrm{mm}$ of halo diameter without growth around the disks [40]. Each bacterial strain was tested in duplicate and the halo of the inhibition zones measured using a vernier caliper rule. The average and the respective standard deviation (SD) of the three replicates were recorded.

\subsection{Minimum Inhibitory Concentration (MIC)}

The MIC is the lowest concentration of antimicrobial agent that completely inhibits growth of the organism in microdilution wells as detected by the unaided eye [40]. MIC values were determined according to the microwell dilution method [41], with small adjustments. Briefly, 96-microplate wells were prepared by adding 12 dilutions of LEO in Lysogeny broth, from $7.5 \%$ to $0.0037 \%$, a growth control without treatments, a control with the same percentage (from $5 \%$ to $0.002 \%$ ) of dimethyl sulfoxide (DMSO) used to solubilise LEO in an aqueous medium, a positive control with gentamicin diluted from 100 to $0.049 \mu \mathrm{g}$, and a sterility control without bacteria. In all wells, except for the sterility control, $50 \mu \mathrm{L}$ of inoculum, previously diluted from $10^{8}$ to $10^{6} \mathrm{CFU} / \mathrm{mL}$, were added and the plates were incubated for $20 \mathrm{~h}$. To better visualise the inhibition activity, $20 \mu \mathrm{L}$ of a solution $200 \mu \mathrm{g} / \mathrm{mL}$ of 3-(4,5-dimethylthiazol-2-yl)-2,5-diphenyltetrazolium bromide (MTT) were added. The assay was carried out in triplicate.

\subsection{Minimum Bactericidal Concentration (MBC)}

Before adding MTT to display the effective bacteria growth, $10 \mu \mathrm{L}$ of the last four dilutions with no presence of turbidity were plated in an agarised Petri plate with LB agar and incubated for $24 \mathrm{~h}$. The MBC was evaluated as the lowest concentration where no growth on agar occurred. The assay was carried out in triplicate.

\subsection{Vapour Phase Test (VPT)}

The antibacterial activity of LEO vapour phase was evaluated by the modified disk volatisation methods [42-44]. Briefly, $15 \mathrm{~mL}$ of liquid LB agar were poured into a $90 \mathrm{~mm}$ plastic Petri dish and 5 
$\mathrm{mL}$ into its cover to prevent interactions between the plastic and LEO. After solidification, the fresh bacterial suspension containing $10^{8} \mathrm{CFU} / \mathrm{mL}$ was inoculated in the medium. Different aliquots of LEO were put in a $6 \mathrm{~mm}$ sterile disk: 40,20, and $2 \mu \mathrm{L}$. A negative control was prepared with a plate without LEO. Liquid LB agar was put in the space between the cover and the base of the Petri dishes to facilitate the sealing. During the solidification time, the Petri dishes were sealed with the aid of an adhesive tape to hold the edges of the plate with its respective counterpart to prevent any LEO leakage. The dishes were put into a plastic bag and incubated for $24 \mathrm{~h}$. After the incubation time, the presence or absence of microbes was visually evaluated and the plates were checked after seven days to investigate the bactericidal or bacteriostatic activity. All VPTs were carried out in triplicate.

\subsection{Statistical Analysis}

The results were expressed as means \pm standard deviation (SD). Data were analysed with one-way analysis of variance (ANOVA) using GraphPad Prism software (GraphPad Prism 5.0, GraphPad Software, Inc., San Diego, CA, USA), with $p$ values $\leq 0.05$ as statistically significant.

\section{Conclusions}

This work aimed to chemically characterise the vapour and liquid phase of L. X intermedia "Grosso" essential oil (LEO).

Its main components were linalool and linalyl acetate followed by 1,8-cineole and terpinen-4-ol. Antimicrobial activity was also tested and the results showed a bactericidal effect on $\mathrm{G}^{-}$bacteria and a bacteriostatic effect on $\mathrm{G}^{+}$bacteria with an overlapping trend for the vapour and liquid phases. Lavandin, a natural sterile hybrid obtained by crossing L. angustifolia $\times$ L. latifolia and grown in the Lazio Region, Italy, was characterised for the first time in this work. Future studies will occur to test the single or combined activity of the main constituents and their possible uses in cosmetic, food, and pharmaceutical fields

Author Contributions: Conceptualisation, S.G. and E.O.; chemical investigation, S.G.; antibacterial investigation G.T. and V.L.M.; writing —original draft preparation, S.G. and E.O; writing - review and editing, S.G., A.T., and E.O.; supervision, P.G; funding acquisition, A.T. All the authors critically edited the manuscript before submission.

Funding: This research received no external funding.

Acknowledgments: We thank Azienda Agricola Podere dell'Arco (Viterbo, Lazio) for providing us (L. $\times$ intermedia "Grosso") essential oil.

Conflicts of Interest: The authors declare no conflict of interest with the agricultural enterprise, Azienda Agricola Podere dell'Arco (Viterbo, Lazio).

\section{References}

1. Bozin, B.; Mimica-Dukic, N.; Simin, N.; Anackov, G. Characterization of the volatile composition of essential oils of some lamiaceae spices and the antimicrobial and antioxidant activities of the entire oils. J. Agric. Food Chem. 2006, 54, 1822-1828. [CrossRef] [PubMed]

2. Nikolić, M.; Jovanović, K.K.; Marković, T.; Marković, D.; Gligorijević, N.; Radulović, S.; Soković, M. Chemical composition, antimicrobial, and cytotoxic properties of five Lamiaceae essential oils. Ind. Crop. Prod. 2014, 61, 225-232. [CrossRef]

3. Mamadalieva, N.Z.; Akramov, D.K.; Ovidi, E.; Tiezzi, A.; Nahar, L.; Azimova, S.S.; Sarker, S.D. Aromatic Medicinal Plants of the Lamiaceae Family from Uzbekistan: Ethnopharmacology, Essential Oils Composition, and Biological Activities. Medicines 2017, 4, 8. [CrossRef] [PubMed]

4. Malcolm, B.J.; Tallian, K. Essential oil of lavender in anxiety disorders: Ready for prime time? Ment. Health Clin. 2018, 7, 147-155. [CrossRef] [PubMed]

5. Nieto, G. Biological Activities of Three Essential Oils of the Lamiaceae Family. Medicines 2017, 4, 63. [CrossRef] [PubMed] 
6. Tanrikulu, G.İ.; Ertürk, Ö.; Yavuz, C.; Can, Z.; Çakir, H.E. Chemical compositions, antioxidant and antimicrobial activities of the essential oil and extracts of Lamiaceae Family (Ocimum basilicum and Thymbra spicata) from Turkey. Int. J. Sec. Metabol. 2017, 4, 340-348. [CrossRef]

7. Upson, T. The taxonomy of the genus. In Lavender: The Genus Lavandula; Lis-Balchin, M., Ed.; Taylor \& Francis Inc.: London, UK, 2002; Volume 2, pp. 2-34.

8. Gols, R. Direct and indirect chemical defences against insects in a multitrophic framework. Plant Cell Environ. 2014, 37, 1741-1752. [CrossRef] [PubMed]

9. Sharifi-Rad, J.; Sureda, A.; Tenore, G.; Daglia, M.; Sharifi-Rad, M.; Valussi, M.; Tundis, R.; Sharifi-Rad, M.; Loizzo, M.R.; Ademiluyi, A.O.; et al. Biological Activities of Essential Oils: From Plant Chemoecology to Traditional Healing Systems. Molecules 2017, 22, 70. [CrossRef]

10. Baser, K.H.C.; Buchbauer, G. Handbook of Essential Oils. Science, Technology, and Applications, 2nd ed; CRC Press: Boca Raton, FL, USA, 2015. [CrossRef]

11. Gautam, N.; Mantha, A.K.; Mittal, S. Essential oils and their constituents as anticancer agents: A mechanistic view. BioMed Res. Int. 2014, 2014, 154106. [CrossRef]

12. Dhifi, W.; Bellili, S.; Jazi, S.; Bahloul, N.; Mnif, W. Essential Oils' Chemical Characterization and Investigation of Some Biological Activities: A Critical Review. Medicines 2016, 3, 25. [CrossRef]

13. Elshafie, H.S.; Camele, I. An overview of The Biological Effects of Some Mediterranean Essential Oils on Human Health. BioMed Res. Int. 2017, 2017, 9268468. [CrossRef]

14. Hajhashemi, V.; Ghannadi, A.; Sharif, B. Anti-inflammatory and analgesic properties of the leaf extracts and essential oil of Lavandula angustifolia Mill. J. Ethnopharmacol. 2003, 89, 67-71. [CrossRef]

15. Miguel, M.G. Antioxidant and Anti-Inflammatory Activities of Essential Oils: A short review. Molecules 2010, 15, 9252-9287. [CrossRef]

16. Schuwald, A.M.; Nöldner, M.; Wilmes, T.; Klugbauer, N.; Leuner, K.; Müller, W.E. Lavender oil-potent anxiolytic properties via modulating voltage dependent calcium channels. PLoS ONE 2013, 8, e59998. [CrossRef]

17. Poyton, C.; Manchadi, M.L.; Cheesman, M.; Lavidis, N. Effects of Lavender and Linalool on Neurotransmission and Contraction of Smooth Muscle. Pharmacogn. Commun. 2015, 5, 217-225. [CrossRef]

18. Donadu, M.G.; Usai, D.; Mazzarello, V.; Molicotti, P.; Cannas, S.; Bellardi, M.G.; Zanetti, S. Change in Caco-2 cells following treatment with various lavender essential oils. Nat. Prod. Res. 2017, 31, 2203-2206. [CrossRef]

19. Cardia, G.F.E.; Silva-Filho, S.E.; Silva, E.L. Effect of Lavender (Lavandula angustifolia) Essential Oil on Acute Inflammatory Response. Evid-Based Complement. Altern. 2018, 2018, 1413940. [CrossRef]

20. Moon, T.; Wilkinson, J.M.; Cavanagh, H.M. Antiparasitic activity of two Lavandula essential oils against Giardia duodenalis, Trichomonas vaginalis and Hexamita inflata. Parasitol. Res. 2006, 99, 722-728. [CrossRef]

21. Mori, H.M.; Kawanami, H.; Kawahata, H.; Aoki, M. Wound healing potential of lavender oil by acceleration of granulation and wound contraction through induction of TGF- $\beta$ in a rat model. BMC Complement. Altern. Med. 2016, 16, 144. [CrossRef]

22. Lis-Balchin, M.; Hart, S. Studies on the mode of action of the essential oil of lavender (Lavandula angustifolia P. Miller). Phytother. Res. 1999, 13, 540-542. [CrossRef]

23. Rota, C.; Carraminana, J.J.; Burillo, J.; Herrera, A. In vitro antimicrobial activity of essential oils from aromatic plants against selected foodborne pathogens. J. Food. Prot. 2004, 67, 1252-1256. [CrossRef]

24. Soković, M.; Marin, P.D.; Brkć, D.; Van Griensven, L.J.L.D. Chemical composition and antibacterial activity of essential oils of ten aromatic plants against human pathogenic bacteria. Food 2007, 1, 220-226.

25. Martucci, J.F.; Gende, L.B.; Neira, L.M.; Ruseckaite, R.A. Oregano and lavender essential oils as antioxidant and antimicrobial additives of biogenic gelatin films. Ind. Crops Prod. 2015, 71, 205-213. [CrossRef]

26. Smigielski, K.; Prusinowska, R.; Stobiecka, A.; Kunicka-Styczyñska, A.; Gruska, R. Biological Properties and Chemical Composition of Essential Oils from Flowers and Aerial Parts of Lavender (Lavandula angustifolia). J. Essent. Oil Bear. Plants 2018, 21, 1303-1314. [CrossRef]

27. Park, C.H.; Park, Y.E.; Yeo, H.J.; Chun, S.W.; Baskar, T.B.; Lim, S.S.; Park, S.U. Chemical Compositions of the Volatile Oils and Antibacterial Screening of Solvent Extract from Downy Lavender. Foods 2019, 8, 132. [CrossRef]

28. Tardugno, R.; Serio, A.; Pellati, F.; D’Amato, S.; Chaves López, C.; Bellardi, M.G.; Di Vito, M.; Savini, V.; Paparella, A.; Benvenuti, S. Lavandula x intermedia and Lavandula angustifolia essential oils: Phytochemical composition and antimicrobial activity against foodborne pathogens. Nat. Prod. Res. 2018, 21,1-6. [CrossRef] 
29. Lesage-Meessen, L.; Bou, M.; Sigoillot, J.C.; Faulds, C.B.; Lomascolo, A. Essential oils and distilled straws of lavender and lavandin:a review of current use and potential application in white biotechnology. Appl. Microbiol. Biotechnol. 2015, 99, 3375-3385. [CrossRef]

30. Ghelardini, C.; Galeotti, N.; Salvatore, G.; Mazzanti, G. Local anaesthetic activity of the essential oil of Lavandula angustifolia. Planta Med. 1999, 67, 564-566. [CrossRef]

31. Caputo, L.; Souza, L.F.; Alloisio, S.; Cornara, L.; De Feo, V. Coriandrum sativum and Lavandula angustifolia Essential Oils: Chemical Composition and Activity on Central Nervous System. Int. J. Mol. Sci. 2016, 17, 1999. [CrossRef]

32. Bajalan, I.; Rouzbahani, R.; Pirbalouti, A.G.; Maggi, F. Chemical Composition and Antibacterial Activity of Iranian Lavandula $\times$ hybrida. Chem. Biodivers. 2017, 14, e1700064. [CrossRef]

33. Jianu, C.; Pop, G.; Gruia, A.T.; Horhat, F.G. Chemical composition and antimicrobial activity of essential oils of lavender (Lavandula angustifolia) and lavandin (Lavandula x intermedia) grown in Western Romania. Int. J. Agric. Biol. 2013, 15, 772-776.

34. Verma, R.S.; Rahman, L.U.; Chanotiya, C.S.; Verma, R.K.; Chauhan, A.; Yadav, A.; Singh, A.; Yadav, A.K. Essential oil composition of Lavandula angustifolia Mill. cultivated in the mid hills of Uttarakhand, India. J. Serbian Chem. Soc. 2010, 75, 343-348. [CrossRef]

35. Peracino, V.; Caramiello, R.; Maffei, M. Essential oils from same Lavandula hybrids growing spontaneously in North West Italy. Flavour Fragr. J. 1994, 9, 11-17. [CrossRef]

36. Pistelli, L.; Giovanelli, N.S.; Lorenzini, L.; Tavarini, S.; Angelini, L.G. Agronomic and phytochemical evaluation of lavandin and lavender cultivars cultivated in the Tyrrhenian area of Tuscany (Italy). Ind. Crop Prod. 2017, 109, 37-44. [CrossRef]

37. Garzoli, S.; Laghezza Masci, V.; Turchetti, G.; Pesci, L.; Tiezzi, A.; Ovidi, E. Chemical investigations of male and female leaf extracts from Schinus molle L. Nat. Prod. Res. 2019, 33, 1980-1983. [CrossRef]

38. Oliva, A.; Costantini, S.; De Angelis, M.; Garzoli, S.; Bozovic, M.; Mascellino, M.T.; Vullo, V.; Ragno, R. High potency of Maleleuca Alternifolia essential oil against multi-drug resistent Gram-negative bacteria and methicillin-resistant Staphyloccocus aureus. Molecules 2018, 23, 2584. [CrossRef]

39. Oliva, A.; Garzoli, S.; Sabatino, M.; Andreotti, E.; Tadic, V.; Costantini, S.; Ragno, R.; Bozovic, M. Chemical composition and antimicrobial activity of essential oil of Helichrysum italicum (Roth) G. Don fil. (Asteraceae) from Montenegro. Nat. Prod. Res 2019. [CrossRef]

40. Balouiri, M.; Sadiki, M.; Ibnsouda, S.A. Methods for in vitro evaluating antimicrobial activity: A review. J. Pharm. Biomed. Anal. 2016, 6, 71-79. [CrossRef]

41. Clinical and Laboratory Standards Institute. M23-A3: Development of In Vitro Susceptibility Testing Criteria and Quality Control Parameters; Approved Guideline, 3rd ed.; CLSI Document; Clinical and Laboratory Standards Institute: Wayne, PA, USA, 2008; Volume 28.

42. Lopez, P.; Sanchez, C.; Battle, R.; Nerin, C. Solid-and Vapor-Phase Antimicrobial Activities of Six Essential Oils: Susceptibility of Selected Foodborne Bacterial and Fungal Strains. J. Agric. Food Chem. 2005, 53, 6939-6946. [CrossRef]

43. Nedorostova, L.; Kloucek, P.; Kokoska, L.; Stolcova, M.; Pulkrabek, J. Antimicrobial properties of selected essential oils in vapour phase against foodborne bacteria. Food Control 2009, 20, 157-160. [CrossRef]

44. Tyagi, A.K.; Malik, A. Morphostructural Damage in Food-Spoiling Bacteria due to the Lemon Grass Oil and Its Vapour: SEM, TEM, and AFM Investigations. Evid. Based Complement. Altern. Med. 2012, 2012, 692625. [CrossRef]

Sample Availability: LEO sample is available from the authors. 